\title{
Research on Application Ability of Innovative and Entrepreneurial Intellectual Property in Undergraduate Universities
}

\author{
Dong Wang, Zhou Yang, Li Ting
}

School of Vehicle Engineering, Xi’an Aeronautical University, Xi’an, China

Keywords: College students; Social background; Innovation and entrepreneurship; Intellectual property rights

\begin{abstract}
With the increasing social concern of College Students' innovation and entrepreneurship, the importance of knowledge innovation to drive students' entrepreneurship is becoming more and more important in the ability training of college students. This paper mainly explores the problems of the application ability of the intellectual property rights of the undergraduate college students in the current social environment, focusing on the analysis of the current situation, summarizing the problems, and summarizing the reasons, and then puts forward some relevant measures to help improve the ability of the application of intellectual property rights for College Students' innovation and entrepreneurship.
\end{abstract}

\section{Introduction}

The application ability of the intellectual property rights of College Students' innovation and entrepreneurship is manifested in two levels of knowledge innovation and knowledge application. Knowledge innovation shows that college students put forward new methods or new tools for the market demand, thus forming a new form of satisfying the social needs, which belong to the laboratory application, and the knowledge application refers to the college students. The form of entrepreneurship transforms the above innovations into products or services that can be operated in a large scale, thereby creating economic benefits. The two complement each other and are always run by intellectual property rights. It is not only the driving force of university students' entrepreneurship, but also the driving force of university students' innovation.

College Students' innovation and entrepreneurship is an important issue related to the livelihood of the community, and also constitutes an important part of the whole social transformation. The purpose of education is to deliver enough people to meet the needs of the society. Therefore, the innovation and Entrepreneurship of college students must be bound by all aspects of society, such as social needs, social environment, social recognition, etc. Objectively speaking, the social demand is the motive force of the college students' innovation and entrepreneurship, and the social environment is the foundation of the college students' innovation and entrepreneurship, and the social recognition is the important standard [1] for the college students to innovate and start a business. Based on this, to strengthen the social perspective of college students to look at innovation and entrepreneurship, can better enhance the social matching of College Students' innovation and entrepreneurship, so as to gain more social support and help to establish a proper and effective way of innovation and entrepreneurship for college students.

\section{College Students' Entrepreneurship, New Business, Intellectual Property Application Ability}

\subsection{Cognitive status of intellectual property rights application}

The foundation of College Students' innovation and entrepreneurship lies in sufficient knowledge and cognition, so how to strengthen the university students' reserve in the knowledge level and to accept and enrich the knowledge of innovation and entrepreneurship is the most basic and key content. In this process, the extensive knowledge system based on university general education, the 
in-depth professional knowledge based on the university professional education and the theoretical education and practical guidance on the level of policy, management, market and service at the level of innovation and entrepreneurship at the level of innovation and entrepreneurship are all [2]. The past, present and future trend of society has a certain effect on the process of College Students' innovation and entrepreneurship.

For example, expectations of future prospects often affect people's support for the intensity and persistence of College Students' innovation and entrepreneurship. For the prospect and the bright trend of the university students' innovation and entrepreneurship policy, the support will be greater, the support time will be longer, and the trend is blurred, the difficult prospects for college students innovation and entrepreneurship policy is often faced with the embarrassing situation of support, resulting in the failure of innovation and Entrepreneurship of the students. From the current situation, colleges and universities have completed the cultivation of patent retrieval awareness on the level of intellectual property rights of College Students' innovation and entrepreneurship, thus helping students to avoid repetition better and improve the success rate of College Students' entrepreneurial success based on knowledge innovation.

\subsection{Present situation of the application of intellectual property}

When university students enter into the practice stage of innovation and entrepreneurship, social needs will be transformed into social support. This possibility is [3] determined by social environment. The social, political, economic and cultural fields play a significant role in the process of College Students' innovation and entrepreneurship. For example, in provinces and cities with different economic development levels, the degree of difficulty in promoting the innovation and Entrepreneurship Program of the same university students is quite different. The higher economic level can provide sufficient and continuous funding support for college students to innovate and start up, thus providing the necessary guarantee for the university students to expand their scale, add content and improve their level, while the economic embarrassment inevitably makes the college students' innovation and entrepreneurship into the plight of rice cooking without rice.

The most important thing for university students to start their business is to expand the market by knowledge innovation, and the content of knowledge innovation is the core [4] of College Students' entrepreneurship. When the knowledge innovation is transformed into a specific product or service, the university student entrepreneurs need to build their own team. For the core members, the core knowledge innovation of the team does not have too high secrecy. Once the problem of leakage occurs, it is a destructive blow to the venture. Therefore, we should attach importance to the protection of intellectual property in the preparatory stage. In addition to actively declaring relevant patents and obtaining legal protection, it should also sign a confidential contract with the core members in order to reduce the risk of operation.

\subsection{Present situation of the application and transformation of intellectual property}

Social thought, system, material and other conditions have a significant impact on the process of College Students' innovation and entrepreneurship, [5]. For example, under the current administrative standard education management system and educational evaluation system of our country, these two systems are still the extension and practice of the social related system in the field of education. Therefore, if the social related system is not changed, then the educational management system and the education evaluation system can only be small in detail. Weak change can not change the fundamental force of the standard system and the basic system, so that the innovation and Entrepreneurship of college students become a mere formality.

On the one hand, as the main core of knowledge innovation, trademark registration and patent declaration are the core content. Therefore, it is necessary to involve the related contents of the trademark law and the patent law, [6]. University students should not only protect their trademark and knowledge innovation, but also pay attention to infringement of others' trademarks and patents. Therefore, we should strengthen the teaching and guidance of this part in the process of training college students' ability to protect intellectual property rights in innovation and entrepreneurship. From the present situation, although a considerable number of colleges and universities have 
already had a certain form of trademark and patent education, but the overall performance of the knowledge is too broad, and does not form a systematic teaching procedure and clear teaching objectives.

On the other hand, the market value of College Students' knowledge innovation is gradually paid attention to when the college students enter the growth period, with the process of expanding the scale of business. At the same time, how to reduce the conflicts of interest in the process of cooperation with partners, and to ensure that their own knowledge creation and intellectual property rights should also be in college students. The key contents in the training of intellectual property rights in innovation and entrepreneurship, but the reality shows that the content of universities in this part is also lacking.

\section{College Students' Innovation and Entrepreneurship Training of Intellectual Property Rights}

\subsection{Lack of understanding}

In the intellectual property education of innovation and entrepreneurship in Colleges and universities, from the management team to the education team, the intellectual property protection of the university students in the process of entrepreneurship is lacking enough understanding, and the importance is seriously insufficient. A universal miscognition is that the related content of intellectual property belongs to the legal content. For the students of the illicit science major, this part of the content is not necessary for the study. In such a cognitive environment, the cultivation of the ability to apply intellectual property has not formed due attention. Most colleges and universities have not established a systematic and standardized intellectual property education system, nor have they formed a specialized and scientific research field of intellectual property rights, resulting in the overall effect of education and teaching. Low. In addition, because of the lack of knowledge of intellectual property rights, college students have failed to strengthen the protection of intellectual property rights and have not formed a linkage with the intellectual property management departments in the process of innovation and entrepreneurship, resulting in lack of understanding of relevant intellectual property rights policies, resulting in the overall lack of understanding.

\subsection{Lack of resources leads to limited teaching methods}

Intellectual property rights not only have theoretical knowledge content that involve legal rules and regulations, but also involve the application practice of registration and protection. Therefore, colleges and universities should guide students to enrich their relevant theoretical knowledge and related practical application in the training of intellectual property rights of students' innovation and entrepreneurship, for example, after the completion of knowledge innovation. A clear idea of intellectual property declaration and protection, including what kind of patents it belongs to, how to apply for patents, and how to safeguard rights according to law in the event of infringement. However, from the actual situation, in this part of the education of this part of the education, the theoretical knowledge part of the legal rules and regulations has a certain progress, and the application of practical guidance is not obvious.

\subsection{Lack of Teachers}

From the perspective of teaching practice, most of the teachers in charge of intellectual property courses are school law teachers. Most of them are full-time teachers who are engaged in law teaching in the first line of the year. They are very good at mastering legal rules and regulations, but they are generally lack of practical experience. At the same time, they have a patent for technology and innovation based on science and technology. At the same time, the self-protection intervention procedures of laws and regulations in the actual operation of enterprises are also strange. Therefore, colleges and universities are generally lack of comprehensive literacy teachers with the background of science and technology, the practice of laws and regulations and the rich legal knowledge. 


\section{Measures to Enhance Intellectual Property Education and Improve College Students' Ability of Innovation and Entrepreneurship}

\subsection{Increase the input of resources and enrich the form of teaching}

Colleges and universities should actively increase the investment in intellectual property education. On the basis of existing education and teaching, we should enrich the content of teaching and diversify the form of teaching. On the basis of making full use of traditional classroom teaching mode to improve the knowledge of intellectual property rights of students' innovation and entrepreneurship, they should guide students to participate actively and master knowledge production. Right application practice, at the same time, through a variety of measures, such as knowledge forum, award collection, knowledge competition, and the popularization of the board and other measures to enhance the students' practical participation, the conditional schools can even participate in the trial and analysis of intellectual property cases, further expand the students' knowledge of the application of intellectual property.

\subsection{Improve the comprehensive literacy of teachers' intellectual property rights}

On the one hand, we should strengthen the training of teachers, enrich the knowledge of the intellectual property rights of innovation and entrepreneurship through dialogue with experts and face to face questions, and introduce advanced education and teaching ideas to improve the practical experience of teachers' intellectual property education and teaching in innovation and entrepreneurship.

On the other hand, teachers in the education of intellectual property education are encouraged to actively participate in the social practice positions related to intellectual property rights, so as to further enrich the practical experience in the field of intellectual property rights, thus effectively improving the practical guidance of the teaching of intellectual property.

\subsection{Improve the effective docking with the external society}

The effectiveness of university students' innovation and entrepreneurship needs not only the evaluation of the education system itself, but also the evaluation of the external society. It should be double recognition from the perspective of education system and society. From the essence of College Students' innovation and entrepreneurship, this is still a social affair. Therefore, in addition to the professional recognition of the educational system itself, it is necessary for the society to recognize that the college students' innovation and entrepreneurship evaluation is indispensable, which involves the social legitimacy of the college students' innovation and entrepreneurship.

College Students' innovation and entrepreneurship should be the dual standard of moral legitimacy and social legitimacy. The measurement of the former is mainly the education system itself, including whether it is in conformity with the promotion of the overall development of the students' health; whether it is necessary to help the progress of social civilization, it needs to be judged by the degree of social recognition. With the universal recognition of the external society, the innovation and Entrepreneurship of college students may be smooth and successful, and the effect of College Students' innovation and entrepreneurship is likely to continue to play a role. But if no external society generally recognised it, the process of its promotion will be doomed to difficulties and its so-called effectiveness will not last long. It is based on this understanding that in recent years, some places have begun to pay attention to the social evaluation of College Students' innovation and entrepreneurship, try to conduct social evaluation of College Students' innovation and entrepreneurship through third party organizations, and take the evaluation results as an important reference for improving and deepening the innovation and Entrepreneurship of college students. In these areas, social evaluation has become an important part of the whole university's innovation and entrepreneurship evaluation. 


\section{Conclusion}

College Students' innovation and entrepreneurship is a complex, simple, difficult and easy thing. This has almost become a social consensus. It is easy and easy for almost everyone to realize that the focus of College Students' innovation and entrepreneurship lies in the education itself and social identity, and that complexity and difficulty are the factors that want to coordinate the two aspects of the internal and external aspects, and it is not easy to establish a proper and effective path for college students to innovate and start a business. In the past a long time, people have paid more attention to the reform of education itself, the rationality of the way of education, the proper distribution of the school district, and the effectiveness of the education policy. This is a widespread concern in the past when it comes to college students' innovation and entrepreneurship. However, as a part of social change, college students' innovation and entrepreneurship have determined the dependence of social elements, including politics, economy and culture, but it is difficult to achieve success only from the reform of education itself. Education itself is not an inherent attribute of education, but an extension of ideology, economy and culture established in all fields of society. Especially in the current social background of China, the social factors play an even more important role in the innovation and Entrepreneurship of college students.

With the deepening of innovation and Entrepreneurship of college students, we should also strengthen the examination of innovation and Entrepreneurship Based on the social perspective. We can not simply bring the innovation and Entrepreneurship of college students into the category of education and campus, but we should establish an open and comprehensive promotion system based on social needs, social environment and social recognition. And gradually formed the innovation and Entrepreneurship Model of college students with social demand as the motive force, social environment as the basis, social recognition as the important standard, and closely related to the society. Only in this way can the innovation and Entrepreneurship of college students take root in the soil of social practice, from the starting stage, the promotion stage and the feedback stage of the college students' innovation and entrepreneurship, to establish the whole social impetus, so as to form a positive exploration for the supporting elements of the College Students' innovation and entrepreneurship. Establish a broad, profound, appropriate, reasonable and effective way for college students to innovate and start their own businesses.

\section{Acknowledgements}

Shaanxi province educational science planning subject (SGH17H377); Xi'an aeronautical institute teaching reform research project (17JG09)

\section{References}

[1] Jia Yinshi, Liang Yan. Analysis of the cultivation of intellectual property in the innovation and entrepreneurship education of university students [J]. Legal System and Economics, 2016, (10): 46-47.

[2] Zhang Ting, Wang Yi. On the cultivation of College Students' innovation and entrepreneurship and intellectual property quality education [J]. Education of the times, 2015, (23): 133+140+2.

[3] Yang Lin, Sheng Yan, Dong Binrong. Research on the education structure of intellectual property in university students' innovation and entrepreneurship education from the perspective of University [J]. Newsletter of Vocational Education, 2014, (36): 73-75.

[4] Zhang Wujun. Research on intellectual property rights in innovation and Entrepreneurship of college students [A]. science and technology progress and Countermeasures magazine. Science and technology progress and system reform and "scientific and technological progress and Countermeasures" 30th anniversary academic forum papers [C]. Science and Technology Progress and Countermeasures magazine: 2014:3.

[5] Shen Hui, Yin Zhiguo. The path of intellectual property education in the training of 
entrepreneurial college students [J]. China Adult Education, 2014, (06): 57-59.

[6] Yang Chen, Xie Yulian, Cai Yun. Analysis on the training system of intellectual property services for innovative and entrepreneurial university students [J]. China Science and Technology Forum, 2013, (10): 112-117. 